\title{
Talking to God: conceptualising an alternative politeness approach for the human/divine relationship
}

\begin{abstract}
The human/divine relationship is a dynamic that does not easily fit into existing politeness research frameworks and approaches. This paper will look to explore this relationship further, within the ancient Egyptian Late Ramesside Letters (c. 10991069 BCE), in order to explore the limitations of facework and ritual in fully exploring the phenomenon, and offer an alternative approach - the 'community-embedded' model - , which expands on principles from both Facework and Ritual, as well as collective prayer. The use here of the 'community-embedded' approach allows for the analysis of the impact of utterances to and involving God (the divine entity who assumes this role in the communicative interaction) within wider social networks and how this supports simultaneous relationship maintenance between the humans, God, and larger networks specific to the culture under review.
\end{abstract}

Key words: Human/God relationship; Late Ramesside Letters; Facework; Social Ritual; Religious Ritual.

\section{Introduction}

There are certain contexts and certain relationship dynamics that do not explicitly lend themselves to analysis via traditional politeness research approaches. This is in part because politeness in interaction is predominantly viewed as a two-way process between two identifiable interlocutors. Yet, not all interaction occurs within this often static dynamic, and alternative approaches are needed to explore the linguistic phenomena that appear in utterances but which maintain relationships outside of the standard model. The relationship maintenance between humans and God ${ }^{1}$ certainly falls into this category and this paper will look to explore the human/divine relationship further, via the ancient Egyptian Late Ramesside Letters (c.1099-1069 BCE), to highlight the limitations of using both mainstream (Facework) and upcoming approaches (linguistic ritual) to analyse this relationship dynamic. In light of these limitations, I will argue for an alternative approach to analysing this relationship, one which has its foundation in the embedded nature of the divine within communities found in research on collective prayer. At the heart of this is the idea that through the human/divine relationship we can explore interactionally situated practices (Terakouafi and Kádár 2017: 186), and how these practices support relationship maintenance with an omnipresent deity, as well as wider community relationships.

Exploring how we linguistically interact with deities has typically revolved around two different academic approaches; how we talk about God (e.g. White 2010) and how we talk to God (e.g. Foist 2015). With regard to talking to God, studies on this theme tend to utilise the traditional communication approach, with the communication being sent between a sender (human) and a receiver (God), ${ }^{2}$ and the channel of the communication taking the form of prayer (Cerulo and Barra 2008: 376). This two-

\footnotetext{
${ }^{1}$ Here the term God is used to refer to the divine entity who assumes this role in the communicative interaction - this could refer to 'gods' plural, multiple genders, or to one specific deity. The nature of God is not under analysis her but rather the role of the actor defined within the interaction as God within the wider communicative event.

${ }^{2}$ Although God is regularly treated as a human in regard to how the communication is analysed (White 2010: 1).
} 
dimensional communicative act reflects a secular approach to divine communication within (predominantly western) academia, one where talking to god is something that is done separately (and often in private) from day-to-day conversations and relationships. Within cultures where religion is more openly practiced, religious utterances have a more prominent role within communication, for example, references to god are often embedded within linguistic conventions, such as within greetings in Arabic: Assalamu Alaikom warahmatu Allahi wa barakatuhu, 'Peace be upon you and Allah's mercy and blessings' (Ferguson 1976: Alsohaibani 2017). For many people around the world communication with the divine is a fundamental part of their lives and they look to manage that relationship through a variety of culturallyspecific linguistic mechanisms in the same way as they manage their relationships with others in their social network (although often via extremely formal linguistic forms). Hence, although this paper utilises ancient Egyptian sources, it has practical applicability and replicability within any study looking to explore how the relationship with the divine is maintained and how this relationship helps to support harmony within culturally specific social networks in which (a) God is embedded and invoked.

\section{Historical Data and Methodology}

For the ancient Egyptians their relationship with the gods around them was fundamental to their continued prosperity (Baines 2001), it was embedded into all aspects of their lived experienced, and worship of the gods ensured their prolonged benevolence. This relationship needed to be maintained through regular worship and signs of deference, but it was very much a reciprocal one (Baines 2001: 25), with the gods bestowing favour on those who fulfilled socially normative behaviour and having their positive face maintained through offerings and prayers. Part of this expected behaviour was the completion of religious rituals, which have received a great deal of scholarly attention (i.e. Teeter 2011), yet the roles these rituals play in linguistically maintaining social relationships with both other human interactants and the divine have yet to be considered. Within this article, I will focus solely on the interpersonal communicative events with, or involving, the god Amun, as captured with the ancient Egyptian Late Ramesside Letters, rather than the mechanisms of the religion itself.

The Late Ramesside Letters (c. 1099-1069 BCE) ${ }^{3}$ are a collection of over 70 texts written in Late Egyptian Hieratic that date to the reign of Ramesses XI, the final king of the New Kingdom. ${ }^{4}$ The community encapsulated in the letters consisted predominately of scribes based on the Theban West Bank, living around the mortuary temple of Ramesses III at Medinet Habu (Hölscher 1954: 5; Stadelmann 1980: 125571).Over 40 of the letters were written by or sent to one particular Scribe of the Necropolis, Dhutmose, and so from these we can recreate his individual social network and his perceived social position within his wider community. Subsequently, this means that we can examine patterns of language use, and determine social distance and power between Dhutmose and the other individuals with whom he was communicating. Ancient Egypt had a firm social hierarchy in place (Ridealgh 2016) and so within the letters we can also see patterns that establish a superior/subordinate relationship dynamic, a dynamic similarly apparent in the relationship Dhutmose shared with his son Butehamun (Ridealgh 2020). Directives

\footnotetext{
${ }^{3}$ The letters are published in these collections: Černý (1939); Wente (1967 \& 1990); Janssen (1991); Demarée (2006).

${ }^{4}$ More information about the letters can be found in the following publications: Černý (1973); Valbelle (1985); Sweeney (2001); Ridealgh (2013 \& 2016).
} 
that feature a religious ritual within the letters somewhat transcend this superior/subordinate dynamic, only appearing in letters between close relational networks, although only socially superior or socially equal individuals can issue a directive to perform a ritual on their behalf (Ridealgh 2020). These types of requests are common in the letters sent between Dhutmose and his son and their close social network, however, they do not tend to appear frequently outside this localised community.

Amun, noticeably, takes centre stage as the most frequently mentioned god in the Late Ramesside Letters. This is not unexpected considering the importance of Amun, or his most dominant manifestation Amun-Ra, at Thebes during the New Kingdom; Thebes was after all the cult centre of Amun (Leitz 2002 I: 305-308.). The temple at Medinet Habu shared a particularly close association with the god Amun, especially his manifestation of Amun-United-with-Eternity (Nelson 1942: 128; Leitz 2002 I: 335336; Haeny 2005: 108). Within the Late Ramesside Letters it is possible to see the extent to which the god became infused in their daily lexical vocabulary. Not only do directives featuring Amun appear frequently, but Amun also supports the very nature of the communicative acts of the letters themselves, initiating the letters and marking the blessings to the recipient in the formal conventionalised introduction.

(1) In life, prosperity, health, and praise to Amun-Ra, king of the gods. I speak to the gods of the land to give you life, prosperity, health, a long lifetime and a great and good old age; to give to you many favours, to allow me to return and fill my embrace in you every day. ${ }^{5}$ (P. Turin Cat. 1972: 2-4; Černý 1939 : 7-8; Wente 1967: 24-27 \& 1990: 185-186).

Three types of communicative acts involving religious rituals are referred to in the Late Ramesside Letters concerning the god Amun or one of his manifestations. These consist of speaking to the god Amun directly (you shall speak to Amun), which is the most common utterance, taking water to the god (do not be neglectful of taking water to his Open Court), and visiting his open court (you shall go to the Open Court of Amun). Examples used within this study, have been selected to highlight the range of requests used within the letters as common strategies to initiate religious rituals. Whilst several different manifestations of the god Amun could be used within the conventionalised formal introductions of the letters, Amun, Amun-United-withEternity, and Amun-of-the-Thrones-of-the-Two-Lands appear most frequently in the ritual utterances within the main text of the letter. These three manifestations of Amun appear to be inextricably linked with the temple at Medinet Habu, and as such, have prominence in letters sent between the inhabitants who lived in the settlement that had developed around the temple. The decision to phrase request acts to a local manifestation of Amun is poignant, as proximity to the gods was believed to increase the chances that the god would hear the request acts. The god physically hearing the request act is also important, and stelae depicting ears and model clay ears were left at shrines and temples to help ensure that the god would hear all request acts made to him (Ausec 2010).

\footnotetext{
${ }^{5}$ Please note all translations are the authors own, as are any errors found within them.
} 


\section{Application of Facework}

Facework has received a great deal of critical review since Brown and Levinson's (1987) pivotal publication and is on the whole is relatively straightforward to apply to the ancient Egyptian data due to the clear power imbalance that existed within the ancient hierarchical society (Ridealgh 2016; Kádár and Ridealgh 2019: 176). Perhaps one of the short comings of Facework is the lack of a framework for exploring FaceEnhancing Acts, a key feature in maintaining relationships within the ancient world. For example, when maintaining relationships with superiors, the ancient Egyptians employed numerous linguistic forms intended to act as Face-Enhancing Acts. The requests discussed in this paper are examples of this. The god Amun is the superior individual within these interactions and the religious ritual requests, invocation of his name, and offerings are all intended as Face-Enhancing acts.

Within directives which instruct the human receiver to speak with the god Amun, the god becomes the recipient of devotion by the human sender, within the Late Ramesside Letters this request is most frequently issued by the Scribe Dhutmose. He petitions Amun for his safe return but does not believe that the act of speaking to Amun from outside the formal boundaries of Egypt can be as successful as petitioning the god in his native Thebes. As such, he repeatedly initiates request acts to his son Butehamun to ensure that the god remembers his devotion. John Baines (2001: 25) comments that Dhutmose is Amun's effective servant, implying some reciprocity between the deity and the individual: it is in the deity's best interest to help their devotee, and as such, it reflects a two-way relationship (Baines and Frood 2011: $3)$.

(2) When this letter reaches you, you shall speak to Amun to bring me back alive. (P. Leiden I 369, 9-10; Černý 1939: 1-2; Wente 1967: 18-19 \& 1990: 178-179)

(3) You should flatter him and say to him to rescue me. (P. Leiden I 369, v.6; Černý 1939: 1-2; Wente 1967: 18-19 \& 1990: 178-179)

(4) And you shall speak to Amun to bring me back intact from Yar, the place where I am abandoned. (P. BN 197 IV, 6; Černý 1939: 13; Wente 1967: 32-33 \& 1990: 200)

Within the context of the letters, references are also made to taking water to the court of Amun and visiting his court to ensure the safety of living individuals in addition to speak with the god. Here, the notion of reciprocity between the deity and the individual is again evident; in return for daily concern, the god will bestow favours on Dhutmose:

(5) Now, do not be neglectful of taking water to his Open Court, and speak to him to save me. (P. BN 199 V-IX+196 V+198 IV, 10-11; Černý 1939: 5-7; Wente 1967: 21-24; 1990: 186-187)

(6) Indeed, I pass the day while I am standing in the Open Court of AmunUnited-with-Eternity, Amenhotep LPH, Nefertari LPH, and Amun-of-theBeautiful-Encounter, saying save and bring him back alive, prospering, and healthy. (P. BM EA 75020, v.1-v.3; Demarée 2006: 19-21)

(7) When this letter reaches you, you shall go to the Open Court of Amun-ofthe-Thrones-of-the-Two-Lands, and take the young children along with you, and you shall flatter him and tell him to keep me safe. (P. Leiden I 369, v.56; Černý 1939: 1-2; Wente 1967: 18-19 \& 1990: 178-179) 
Approaching this analysis from the perspective of Facework highlights that 1) the positive face of the god is maintained via the ritual itself, and 2) Dhutmose's negative face is maintained by his son Butehamun completing the instructed ritual.

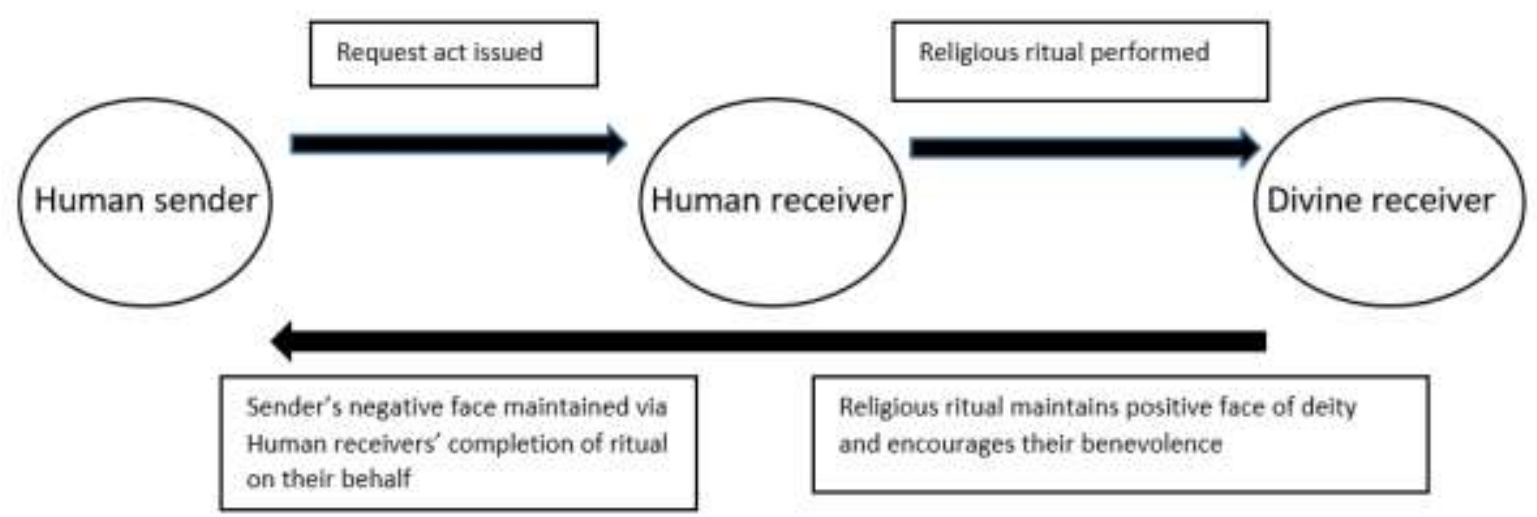

Fig. 1: visual display of linear relationship maintenance when analysed using Facework

The request to speak to the god Amun also appears in letters sent to Dhutmose as a means to maintain good relations with wider community members (although only between socially equally individuals and who were possibly related). In a letter sent by the General's Singer Petahures to Dhutmose only two requests are included in the letter, one is Example (8) below and another is a request for further communication, asking Dhutmose to send Petahures news of his health. The inclusion of the request in a letter to Dhutmose helps to determine the social relationship and power status between the interlocutors and also indicates the normative nature of making such requests.

(8) Speak to Amun-United-with-Eternity and every god of my village to keep me safe with my lord. (P. Geneva D 192, 7-8; Černý 1939: 33-34; Wente 1967: 51 \& 1990: 185)

Dhutmose also receives letters informing him that others have spoken to Amun on his behalf, further preserving the relationship between Dhutmose and Amun, but also demonstrating the role religious request acts plays in maintaining social network members' relationships with Dhutmose by meeting his face wants.

(9) I speak to the gods of the land in which you are in to bring you back alive, prospering, and health and to hand you over to Amun-of-the-Thrones-ofthe-Two-Lands, since you are his beneficial servant. (P. Phillipps, v.4-v.6; Černý 1939: 28-30; Wente 1967: 47-49; 1990: 196-197)

In the examples presented here, it is possible to straightforwardly apply Facework between the human sender and the god. By directing another to complete a ritual to the god Amun on his behalf, Dhutmose in essence appeals to, and attempts to satisfy, Amun's positive face wants in exchange for the god's benevolence, and by having his request fulfilled, Dhutmose's positive face is maintained. There are three main points to highlight here in regards to the role Facework plays in relationship maintenance. Firstly, the vastly different power status between the god Amun and Dhutmose, means that at this point Facework and Discernment Politeness overlap (Ridealgh and Jucker 2019). Amun is socially superior, and, as such, normative behaviour necessitates that Dhutmose must continue to appease Amun's positive 
face wants through Face-Enhancing Acts (such as flattering and offerings) in order to avoid risking his wrath. There are never any references in the letters to Dhutmose believing that Amun was not protecting him. We see the structure of the request acts for rituals remaining consistent but never containing any critical comments towards the god. This is a common feature in Egypt, subordinates do not appear, for the most part, to openly criticise superiors (Ridealgh 2013). However, superiors are free to criticise and impede the actions of their subordinates without it being seen to be a face-threatening act (Ridealgh and Unceta Gomez forthcoming). Dhutmose's relationship with the god Amun is also an extreme version of the superior/subordinate dynamic, and as such, in the eyes of Dhutmose, Amun is free to act as he chooses, but Dhutmose must continue to satisfy his face wants.

Secondly, the relationship is believed by the interactants to be reciprocal. For the ancient Egyptians gods were a lived experienced, embedded in every aspect of their lives, and present as all times. They were dependent on the gods for everything, the Nile flooding, crops growing, birth and rebirth into the afterlife. Religious rituals and paying homage to the god were essential elements of maintaining Amun's face and ensuring that the god would reward individuals with life and prosperity within their belief system. Thus, the god's face is maintained through offerings and utterances, and, as such, the god bestows favours on those making the offerings. In many of the examples included here, such as Example (4), Dhutmose instructs his son to speak and give offerings to Amun. At this time Dhutmose was outside the borders of Egypt, in Nubia (North Sudan), his fear is founded on the worry that the distance from the (localised) god impacts on the continuation of his benevolence. In part this reflects a cultural belief that to truly be Egyptian, you had to live within the borders of Egypt, and more importantly die within the borders; death outside of Egypt's borders meant that the there was a chance you could not access the afterlife. Dhutmose's concern over his wellbeing is entwined with his fear that he will die outside of his homeland.

Thirdly, the role of the intermediary, most commonly Butehamun, Dhutmose's son, is predominantly absent from the analysis of the interaction, although they are completing the request and by doing so maintain the negative face of the initiator of the request act. Even when others write to Dhutmose to inform him that they have spoken to Amun on his behalf, the intermediary's face needs are not as prominent in the interaction as Dhutmose's and Amun's. Requests of this nature are only issued between those socially equally or to socially subordinate kin members - there has to be friendship or kin connection for this request act to be meaningful or appropriate. Yet within this request, it is only the face of the initiator and the god which are effected by the request, Facework is too restrictive to allow for further discussion of the role of, and impact on, the intermediary. Hence using facework to explore social relationships limits us to only being able to view a very specific relationship, that of the human/divine.

\section{$4 \quad$ Application of Ritual}

Whilst Facework is firmly part of the politeness repartee, linguistic ritual is just emerging as an essential pillar of the discipline. Ritual plays a fundamental role in relationship maintenance, and the link with politeness research has been championed by Marcel Bax (2004, 2010a \& 2010b) and Dániel Kádár (2013 \& 2017), who promote linguistic ritual as a relational action constructed in interaction through pre-existing patterns. Kádár (2017: i) highlights that "ritual is a practice through which 
people maintain the order of things, reinforced in each communicative act". This viewpoint is supported by the notion that linguistic ritual plays a significantly more important relational role than marking ceremonies; by means of linguistic ritual acts we work out and maintain interpersonal relationships in diverse ways (Kádár 2017: i). Kádár defines ritual as:

Relational ritual is a formalised and recurrent act, which is relationship forcing; by operating it reinforces/transforms interpersonal relationships. Ritual is realised as an embedded (mini-)performance, and this performance is bound to relational history (and related moral order) or historicity in general (and related moral order). Ritual is an emotively invested action, as anthropological research has shown. (Kádár 2017: 55).

Thus, ritual, in the linguistic sense, has a very specific definition in order to be distinct from linguistic conventions.

In sum, we take convention to be a recurrent and schematic practice, which provides a ready-made solution to a frequently encountered problem; conventions are normative, in that by acting in conventional ways interactants meet contextual expectations and their behaviour is positively evaluated as a result. We take ritual, on the other hand, to be a recurrent action, which re- enacts the ideologies or ethos of a relational network or broader social group as a 'performance', and generates intense emotions and affect (relational emotions) (cf. Kertzer 1988, p. 67). To provide a simple example, singing the national anthem can mean more to many people than simply an interactional convention: it has the potential to be a ritual because by singing it the group of performers are re-enacting their national identities; as with any ritual, this singing event operates for the benefit of a specific audience, it is noticed, emotionally invested, and occurs at a specific time and place. (Terakouafi and Kadar 2017: 172; also Kádár 2017: 87).

When linguistic rituals are used widely within a specific culture or group then they become Social rituals, but when they are only used by smaller relational networks then the ritual is referred to as an In-group ritual as they are incorporated into the expected behaviour of that specific relational network. As Marina Terakouafi and Dániel Kádár (2017: 185) highlight, Social rituals count as socially normative (but not necessarily normative in the interaction of certain relational networks), whilst In-group rituals are practices that count as normative within certain relational networks but are not part of the social norms. It is important to highlight the role linguistic ritual plays in supporting the emotional connection of interlocutors or users of the ritual utterance. As highlighted in the extract above, Ritual "generates intense emotions and affect (relational emotions)" and these can be fundamental in supporting certain relationship dynamics, such as family networks, yet also play an important role in religious experiences. This paper will not delve too deeply here into emotion and emotive language use as it is such a complex topic, however, for the sake of this analysis it is important to acknowledge that certain relationship dynamics generate strong emotions that are essential to the maintenance of that relationship (see Ridealgh forthcoming).

\subsection{Application of In Group Ritual}

In-group rituals are linguistic utterances with a performative element to them, and differ from conventionalised linguistic forms, in that In-group rituals are used to support inclusion in a certain, generally smaller, social network. More specifically, 
these are ritual practices that count as normative within certain relational networks but are not part of the social norm (Terkourafi and Kádár 2017: 185). The ritual utterance is co-constructed between members of this social network as it both 'affects' the participants, i.e. includes them in the social interaction, and triggers an emotive response, i.e. causes an internal individual response.

An example of an in-group ritual in the Late Ramesside Letters can be seen in the phrase 'I am alive today, but tomorrow is in the hands of the god'.

(10) "And you shall give your attention to the Chantress of Amun Shedemduat and her children and Hemetsheri and her little daughter", so said you. I will do! I will do whatever I might be able to do for them. Indeed, they are alive today, but tomorrow is in the hands of the god. You are the one that they desire to see. (P. Geneva D 407, 12-15; Černý 1939: 13-17; Wente 1967: 33-37 \& 1990: 187-188)

(11) Yes! I am alive today, but tomorrow is in the hands of the god. (P. Leiden I 369, 5-6; Černý 1939: 1-2; Wente 1967: 18-19 \& 1990: 178-179)

This phrase is only used by individuals who shared a close relational network (Dhutmose and his family) and only appears after utterances which are specifically health-related. Its purpose in the letters is to provide a shared emotional and religious experience, shared with the divine in the communicative event. Although it is not possible to fully know if the phrase had a performative element due to limited evidence, it does go beyond being a social convention in that the ritual utterances are meaningful for the participants in supporting close social relations. It could also be possible that this utterance is part of socially normative behaviour when explaining one's own health, so may be part of a larger social ritual that we cannot further evidence, but has its foundation in the need to preserve the relationship with the divine. Good health is reliant on the gods, by making assumptions about one's health there is always a risk that you could invoke their wrath.

\subsection{Application of Social Ritual}

Each of the three different request acts found within the Late Ramesside Letters in regards to interacting with the divine via religious rituals also form individual Social rituals:

(12) When this letter reaches you, you shall speak to Amun to bring me back alive. (P. Leiden I 369, 9-10; Černý 1939: 1-2; Wente 1967: 18-19 \& 1990: 178-179)

(13) Now, do not be neglectful of taking water to his Open Court, and speak to him to save me. (P. BN 199 V-IX+196 V+198 IV, 10-11; Černý 1939: 5-7; Wente 1967: 21-24; 1990: 186-187)

(14) When this letter reaches you, you shall go to the Open Court of Amun-ofthe-Thrones-of-the-Two-Lands, and take the young children along with you, and you shall flatter him and tell him to keep me safe. (P. Leiden I 369, v.5-6; Černý 1939: 1-2; Wente 1967: 18-19 \& 1990: 178-179)

Social rituals, in essence, follow very similar functions as In-group rituals with the exception that the normalised behaviour is reflected in a larger number of network members. Like In-group rituals, Social rituals demarcate a co-created experience with the divine for a wider network; the key difference is that Social rituals look to meet, and function within, normative behaviour expectations within a specific culture. A 
clear difference here with Facework is that linguistic ritual allows the focus of the analysis to be placed upon the human interactions, whereas facework focuses on the initiator of the request and the divine.

Sections 4.1. and 4.2 highlight that linguistic ritual is based on a ritual act which is coconstructed, its application can help illuminate the role the religious rituals play in supporting interactionally situated relationship maintenance. Hence when a request is made to perform a religious ritual, the interlocutors co-construct within the request the shared religious experience with the god and both benefit from this and his benevolence. The request has to be made at the appropriate time, i.e. between closely connected kin members and when discussing domestic matters, for it to be successful. It draws upon previously shared experience and the emotional connection to each other, the god, and the cultural value of the religious experience; it allows for a simultaneously shared moment of connection, even if all interactants are geographically separated.

Hence, if the utterances from the Late Ramesside Letters are viewed using Facework alone, the role and maintenance of the relationship with the intermediary would be overlooked in the analysis, by employing linguistic ritual it is possible to observe that actually within the utterance there is not really an 'intermediary' at all, as all the interlocutors play their part in the interaction but that different relationships are maintained simultaneously. This does of course mean that Facework and ritual cannot be used independently of each other, otherwise its risks analysing only certain dynamics of actors within the interaction. Additionally, Ritual also does not allow for the analysis of the linguistic interaction and its role in supporting relationships and expectations outside of the interlocutors within the specific interactions is not clear, i.e. what role this interaction has in supporting a community's relationship with God. Although the utterance maybe classed as a Social ritual, Ritual only allows for the assessment of how the utterance maintains the relationship with the interlocutors and not the role that the utterance as a Social ritual, in its wider sense, helps to support the relationship with the deity in question and the community that adheres to that specific belief system.

\section{Conceptualising an Alternative Approach: The community-embedded approach}

What I have looked to undertake in this paper is to demonstrate the limitations within traditional and upcoming approaches to politeness research. At the moment, we can see that the application of Facework within this data yields very clear results in terms of how the utterances maintained the face of the god, and the application of Ritual demonstrates how close emotional ties between interlocutors were maintained via a shared experience with the divine. Separately, these approaches are restrictive in exploring the embedded relationship maintenance between a culturally specific speech community and an omnipresent deity. The development of an alternative 'community-embedded' approach to exploring the relationship with the divine must bring these two approaches together, along with the role this utterance plays within community networks in maintaining both the relationship with the god and with network members. Theoretical discussions from research on collective prayer can help to provide further insight into the communal nature of speaking to God. As Todd Foist (2015: 523) explains "prayer, whether individual or collective, is inherently 
social, and collective prayer is part of the meaningful practice of communities". More importantly, Foist (2015: 526) highlights that:

The actions and languages used in collective prayer represent social performances (Alexander 2004) that situate the participants within fields of meaning through constructing and maintaining boundaries, delineating categories of identification, structuring emotions, and promoting a group culture.

Within the context of the utterances highlighted in this paper a similar phenomenon to collective prayer is displayed. Amun's name is being invoked within the request, and, as such, the linguistic ritual in the utterance marks the start of the religious ritual and provides the initiation marker for the start of the interaction with the god. This is significant as all actors in the Social ritual are identified at that point, many of whom are not mentioned in the utterance itself but are implied because of the context in which the request appears (i.e. the specific belief system all network members belong to and support). These actors all take part not only in the linguistic ritual (there are no third party observers), but they also participate in the religious ritual, even if they are not physically present: ritual is, after all, a communal action, as highlighted by Dániel Kádár (2017: 8). Thus, what becomes clear is that interactions with the divine rarely appear in isolation, and there are simultaneous interactions happening within utterances and simultaneous relationships being maintained. The first step in the development of an alternative approach is to identify these and explore how they are maintained within the specific dynamic.

If we analyse Example (2) in this manner than we can observe the following:

(2) When this letter reaches you, you shall speak to Amun to bring me back alive. (P. Leiden I 369, 9-10; Černý 1939: 1-2; Wente 1967: 18-19 \& 1990: 178-179)

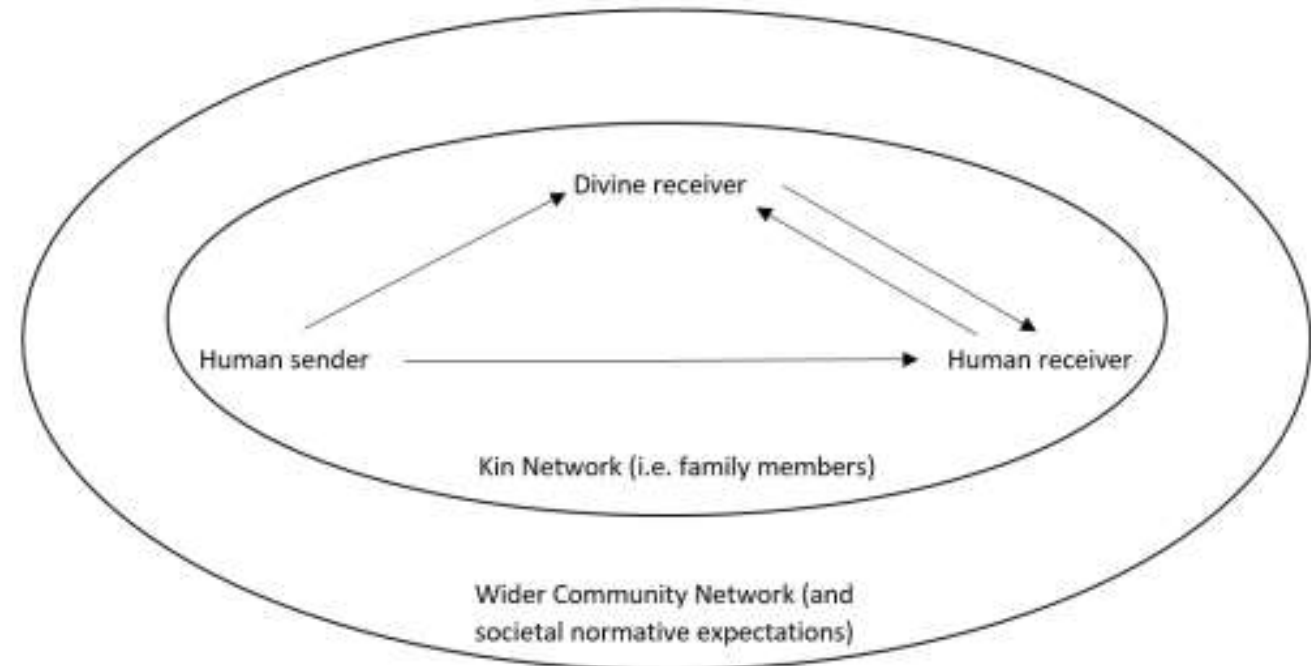

Fig. 3: visual representation of the utterance maintaining distinct culturallyspecific relationships

Within this communicative event, at least five discernible acts of relationship maintenance are present, all of which not only maintain a relationship with the god but also all of the participants simultaneously.

- The (human) sender 
- The direct (human) receiver

- Receiver as omnipresent deity

- The kin network

- The wider community network

A key point to highlight is that although the direct human receiver does receive the message via the channel of the direct utterance, simultaneously another channel for the utterances goes via the god when the god's name is invoked to mark the start of the religious ritual. This means that the direct human receiver not only benefits from the sender's relationship with the god, their own relationship with the god is maintained as the message is channelled via the god. Hence, one utterance can be disseminated via simultaneous channels each being decoded in a different manner. The principle distinction between how these relationships are simultaneously maintained revolves around how the different receivers of the utterance decode and interpret the message.

- The direct (human) receiver: perceives social ritual as a co-constructed and shared experience with both the sender and the god. The social rituals denotes and reinforces the emotional links between the sender, direct human receiver, and the god.

- Receiver as omnipresent deity: the ritual request reinforces the god's positive face wants, supports the superior status of the god, but ensures that the god is embedded into all aspects of daily life, linking social networks; hence providing more opportunities and more active agents in maintaining the god's positive face.

- Receiver as the kin network: perceive the social ritual as part of the normative politic behaviour expected by the close family network; the family members also benefit from the elevated status of the sender and the god's benevolence. The social ritual also provides an opportunity for shared experience and reconnection with a family member in an emotive setting.

- Receiver as the wider community network: perceive the social ritual as part of the normative politic behaviour expected by the community; the community also benefit from the elevated status of the sender and the god's benevolence.

Existing politeness approaches tend to limit who can be a participant within a communicative event:

A participant is an individual in interaction who takes up a particular position or perspective in relation to that talk or conduct. We generally first think of speakers and hearers when the question of who participates in interaction arises. However, we use the terms producer and recipient here, instead of speaker and hearer, to avoid confusion with these commonly used folk terms, as well as to allow that interaction can occur over multiple modes (not just through speech). (Kadar and Haugh 2013: 87)

Dániel Kádár and Michael Haugh (2013: 87) further distinguish participants as ratified and unratified: ratified participants have an active involvement in the interaction and can hold the producer accountable for social actions and meanings that arise through talk. "when we hear talk, however, while it is audible to us and we may (or may not) understand it, we are not expected to attend or directly participate in that talk". Hence, imagine two people speaking on a bus, the ratified participants are those speaking 
with each other, whilst the unratified participants, are those sitting in the bus, who may be listening to the conversation, but are not directly involved. ${ }^{6}$

Within the ancient Egyptian context, all participants are ratified, and their relationships maintained within the communicative act, with all actions that occur being salient for the participants. However, to accommodate this we need to view a spectrum of ratification based essentially on a cost/benefit model, where the participants who utilise most energy within the interaction, i.e. the actual direct sender and receiver(s), experience the highest level of benefit; reversely, the wider community network who invest less energy beyond their involvement in the belief system, gain less benefit, but they are still very much involved in the process and gain benevolence from the deity in question. Yet within this spectrum all participants can hold the producer accountable for their actions, certainly if the producer was critical towards the god or not fulfilling their social obligations to worship the deity. By analysing the communicative event in such a way, we can identify the multidimensional way in which the god interacts with the interlocutors and their community: their relationships are all maintained via these many, but repeated, interactions. Individual interlocutors and the wider community were dependent on the benevolence of the god, just as the god depended on offerings; the reciprocal relationship between god and the community under review is maintained through these many different communicative intentions.

\section{Conclusion}

In summary, existing politeness research approaches often fail to accommodate the analysis of certain relationship dynamics. The human/divine relationship is one of these relationships and this paper has sought to offer an alternative framework to exploring this dynamic, one which is centred on the communally situated linguistic practices and expectations of a wider participant-base then simply the direct human/god dynamic would imply. Within the ancient Egyptian Late Ramesside Letters it is possible to see that maintaining a relationship with God was just as important as maintaining relationships within social networks. Religious rituals and completion of ritual request acts supported the positive face of the beneficiary of the ritual, but they also supported interpersonal relationships by demonstrating the emotional connection of close relational networks through the social ritual aspect of the utterance. The use here of the 'community-embedded' approach allows for the analysis of the impact of utterances to and involving God within wider social networks. Viewing the relationship dynamic through the lens of the ancient world distances the secularism in modern academia perpetuated by predominantly Western scholarship. However, the 'community-embedded' model presented here, which expands on principles from facework, ritual and collective prayer, is certainly applicable to more modern languages and cultures in the pursuit to understand how humans maintain a linguistic relationship with God.

\section{$7 \quad$ Acknowledgements}

Many thanks to the editors and peer reviewers for their valuable comments in further improving this paper.

\footnotetext{
${ }^{6}$ Many thanks to Maria Tsimpiri for this analogy.
} 


\section{Bibliography}

Alsohaibani, Ali. 2017. Influence of religion on language use : a sociopragmatic study on the influence of religion on speech acts performance. PhD Thesis: University of East Anglia, UK.

Alexander, Jeffery C. 2004. Cultural pragmatics: Social performance between ritual and strategy. Sociological Theory 22(4): 527-573.

Ausec, Cindy Lee. 2010. Gods who Hear Prayers: Popular Piety or Kingship in Three Theban Monuments of New Kingdom Egypt. Doctoral dissertation, Dept. of Near Eastern Studies, University of California, Berkeley.

Baines, John. 2001. Egyptian Letters of the New Kingdom as Evidence for Religious Participation and Practice. Journal of Ancient Near Eastern Religions 1: 1-31.

Baines, John \& Elizabeth Frood. 2011. Piety, Change and Display in the New Kingdom. In Mark Collier \& Steven Snape (eds.), Ramesside Studies in Honour of K. A. Kitchen, 1-18. Bolton: Rutherford Press.

Bax, Marcel. 2004. Out of Ritual. A Semiolinguistic Account of the Origin and Development of Indirect Language Behavior. In Marcel Bax, Barend van Heusden \& Wolfgang Wildgen (eds,), Semiotic Evolution and the Dynamics of Culture, 155-213. Bern/Oxford: Peter Lang.

_ 2010a. Rituals. In Handbook of Pragmatics, Vol. 8: Historical Pragmatics, ed. Andeas H. Jucker and Irma Taavitsainen, 483-519. Berlin/New York: Mouton de Gruyter.

— 2010b. Epistolary Presentation Rituals. Face-Work, Politeness, and Ritual Display in Early Modern Dutch Letter-Writing. In Jonathan Culpeper and Dániel Z. Kádár (eds.), Historical (Im)politeness, 37-85. Bern: Peter Lang.

— 2011. An Evolutionary Take on (Im)politeness: Three Broad Developments in the Marking Out of Socio-Proxemic Space. Journal of Historical Pragmatics 12 $(1 / 2):$ 255-282.

Bax, Marcel, and Dániel Z. Kádár. 2013. In-Group Ritual and Relational Work. Journal of Pragmatics 58: 73-86.

Brown, Penelope \& Stephen Levinson. 1987. Politeness: Some Universals in Language Usage, Studies in Interactional Sociolinguistics 4, Cambridge.

Cerulo, Karen \& Andrea Barra. 2008. In the name of...: Legitimate interactants in the dialogue of prayer. Poetics 36(5): 374-388.

Černý, Jaroslav. 1939. Late Ramesside Letters, Bibliotheca Aegyptiaca 9, Brussels.

— 1973. A Community of Workmen at Thebes in the Ramesside Period, Bibliothèque d'étude 50 , Cairo.

Černý, Jaroslav, Sarah Israelit-Groll \& Christopher Eyre. 1984. A Late Egyptian Grammar, 3rd edition, Studia Pohl: Dissertationes scientificae de rebus orientis antiqui (series maior) 4, Rome.

Demarée, Robert. 2006. The Bankes Late Ramesside Papyri, The British Museum Research Publications 155, London. 
Eelen, Gino. 2001. A Critique of Politeness Theories. Manchester.

Ferguson, C. A. (1976) "The structure and use of politeness formulas," Language in Society 5(2): 137-151.

Foist, Todd. 2015. Talking to God Among a Cloud of Witnesses: Collective Prayer as a Meaningful Performance, Journal for the Scientific Study of Religion 54(3): 523-539.

Goffman, Erving. 1955. On Face-Work: An Analysis of Ritual Elements in Social Interaction, in: Psychiatry 18, 213-231.

— 1967. Interaction Rituals: Essays on Face-to-Face Behaviour, New York.

— 1969. The Presentation of Self in Everyday Life, London.

Grice, Paul. 1975. Logic and Conversation. In Peter Cole \& Jerry Morgan (eds.), Syntax and Semantics, Vol. 3: Speech Acts, 41-58. New York: Academic Press.

— 1991. Studies in the Way of Words, Cambridge (Massachusetts).

Haeny, Gerhard. 2005. New Kingdom Mortuary Temples and Mansions of Millions of Years. In Byron Shafer (ed.), Temples of Ancient Egypt, 86-126. London and New York: I. B. Tauris.

Hölscher, Uvo. 1954. The Excavations of Medinet Habu Vol. 5: Post Ramesside Remains. Chicago University Publications 66. Chicago: University of Chicago Press.

Janssen, Jac. 1991. Late Ramesside Letters and Communications, Hieratic Papyri in the British Museum 6, London.

Kádár, Dániel. 2013. Relational Rituals and Communication: Ritual Interaction in Groups. Basingstoke.

— 2017. The Politeness, Impoliteness and Ritual: Maintaining the Moral Order in Interpersonal Interaction. Cambridge.

Kádár, Dániel \& Michael Haugh. 2013. Understanding Politeness, Cambridge.

Kádár, Dániel \& Kim Ridealgh. 2019. Exploring (im)politeness in ancient languages: Introduction. Journal of Historical Pragmatics 20(2): 169-185.

Kertzer, David I. 1988. Ritual, Politics, and Power. New Haven: Yale University Press.

Langlotz, Andreas \& Miriam Locher. 2013. The Role of Emotions in Relational Work, in Journal of Pragmatics 58, 87-107.

Leitz, C. 2002. Lexikon der ägyptischen Götter und Götterbezeichnungen. Leuven, Peeters.

Nelson, Harold. 1942. The Identity of Amun-Ra-United-with-Eternity. Journal of Near Eastern Studies 1: 127-55.

Ridealgh, Kim. 2013. Yes Sir! An Analysis of the Superior/Subordinate Relationship in the Late Ramesside Letters, Lingua Aegyptia: Journal of Egyptian Language Studies 21, 181-206. 
- 2016. Polite like an Egyptian? Case Studies of 'Politeness' in the Late Ramesside Letters, in Journal of Politeness Research 12(2), 245-266.

- 2020. 'Look after him in the Night': Exploring the linguistic manifestation of the father/son relationship dynamic. In Shi-Wei Hsu, Vincent Laisney \& Jan Moje (eds.), Ein Kundiger der in die Gottesworte eingedrugen ist: Festschrift für den Ägyptologen Karl Jansen-Winkeln zum 65 Geburstag, 263-272. Munster: Zaphon.

- 2020. 'Without you I am an Orphan': Exploring Emotion and Interpersonal Pragmatics in the Late Ramesside Letters.

Ridealgh, Kim \& Luis Unceta Gomez. Forthcoming. Potestas and the language of power: Conceptualising an approach to Power and Discernment politeness in ancient languages.

Sharp, Shane. 2010. How does prayer help manage emotions? Social Psychological Quarterly 73(4):417-37.

Stadelmann, Rainer. 1980. Medinet Habu. In Wolfgang Helck \& Wolfhart Westendorf (eds.), Lexikon der Ägyptologie IV, 1255-1271. Wiesbaden: Otto Harrassowitz.

Sweeney, Deborah. 2001. Correspondence and Dialogue: Pragmatic Factors in Late Ramesside Letter Writing, Ägyptologische Abhandlungen 49, Wiesbaden.

Teeter, Emily. 2011. Religion and Ritual in Ancient Egypt. Cambridge: Cambridge University Press.

Terkourafi Marina \& Kádár Dániel. 2017. Convention and Ritual (Im)politeness. In Jonathan Culpeper, Michael Haugh \& Dániel Kádár (eds.), The Palgrave Handbook of Linguistic (Im)politeness, 171-195. Palgrave Macmillan, London.

Valbelle, Dominique. 1985. Les ouvriers de la tombe: Deir el-Médineh à l'époque ramesside, Bibliothèque d'étude 96 , Cairo.

Wente, Edward. 1967. Late Ramesside Letters, Oriental Institute of Chicago Studies in Ancient Oriental Civilisation 33, Chicago.

— 1990. Letters from Ancient Egypt, Society of Biblical Literature: Writings from the Ancient World 1, Atlanta.

White, Roger. 2010. Talking About God: The Concept of Analogy and the Problem of Religious Language. Transcending Boundaries in Philosophy and Theology. Ashgate: Farnham. 